
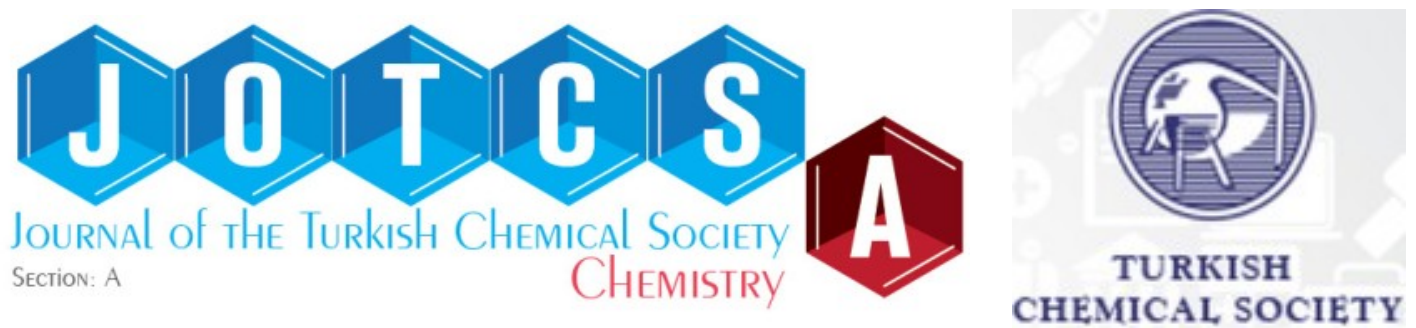

\title{
Chitosan-drug encapsulation as a potential candidate for COVID-19 drug delivery systems: A review
}

\author{
Onome Ejeromedoghene ${ }^{a 1 *} \square D$, Olayinka Oderinde a1* $\square$, , George Egejuru $b \square$, Sheriff \\ Adewuyi ${ }^{*} \rightarrow$ iD \\ a School of Chemistry and Chemical Engineering, Southeast University, Jiangning District, Nanjing, \\ Jiangsu Province, 211189, PR China. \\ ${ }^{b}$ School of Public Health, Southeast University, Jiangning District, Nanjing, Jiangsu Province, 211189, PR \\ China. \\ c Department of Chemistry, College of Physical Sciences, Federal University of Agriculture, PMB 2240, \\ Abeokuta, Ogun State, Nigeria.
}

${ }^{1}$ Authors OE and OO contributed equally to this work and should be regarded as the first author.

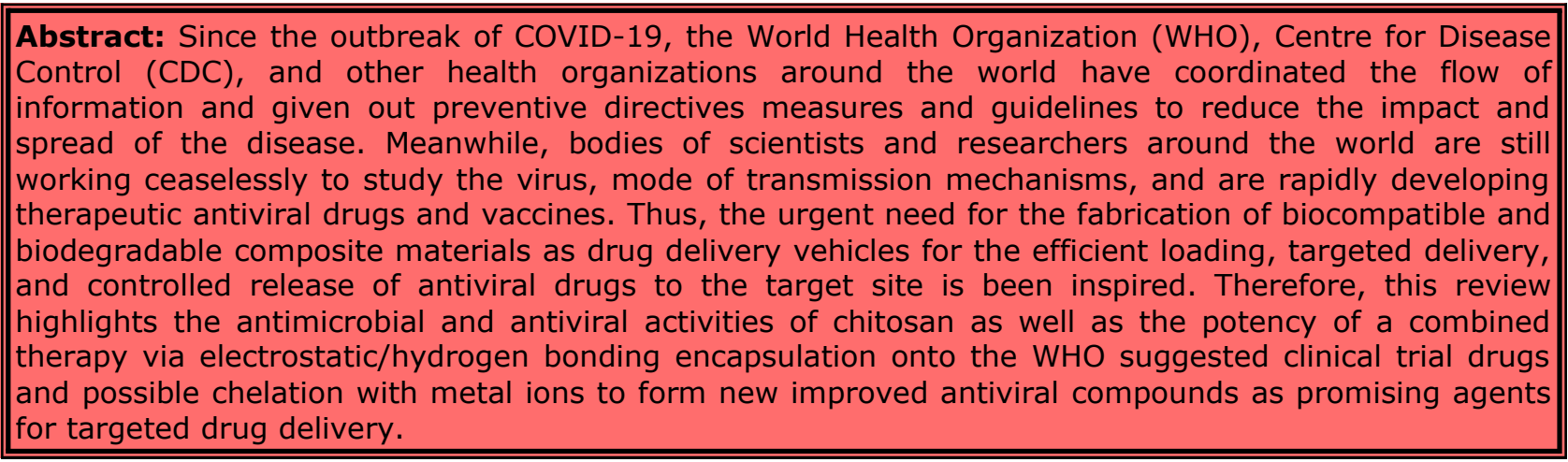

Keywords: COVID-19, Biopolymeric chitosan, Antiviral agent, Drug delivery, Biocompatible, Antibiotics.

Submitted: July 25, 2020. Accepted: October 04, 2020.

Cite this: Ejeromedoghene O, Oderinde O, Egejuru G, Adewuyi S. Chitosan-drug encapsulation as a potential candidate for COVID-19 drug delivery systems: A review. JOTCSA. 2020;7(3):851-64.

DOI: https://doi.org/10.18596/jotcsa.773780.

Corresponding author. E-mail: oejeromedoghene@seu.edu.cn, Tel.: +86-18851663211.

\section{INTRODUCTION}

Since the outbreak of the novel coronavirus disease (COVID-19) which was first identified in December 2019 in China, the World Health Organization (WHO) has considered it as a global epidemic due to its current spread across different countries around the world $(1,2)$. This infectious and deadly disease, formally referred to as Severe Acute Respiratory Syndrome-Coronavirus-2 (SARS-
CoV-2), is caused by a new virus possessing spherical particles resembling crown-shape and bearing proteins called spikes (see Figure 1), protruding from their surfaces that can cling and replicate on the host's cells, hence the general name, coronaviruses (3). The origin of COVID-19 is similar to SARS, also caused by a coronavirus (CoV) that occurred in the seafood and wet animal wholesale market in Wuhan, Hubei Province, China (4). The virus can easily be transmitted by close 
contact between two or more people (via touching, handshake, and hugging), and aerosol transmission (i.e. respiratory droplets from the cough or sneezing of an infected person) $(5,6)$. The clinical manifestation of the disease reported so far is a respiratory involvement, which is linked to mild flu-like illness, potential lethal acute respiratory distress syndrome, or fulminant pneumonia (7). However, other symptoms such as a cough, fever, sore throat, and in more severe cases, difficulty in breathing have also been reported to be attributed with early signs of the contraction of the disease which have an incubation period of about 5 to 14 days (see Figure 2) (8). Although the clinical manifestations of COVID-19 are subject to frequent changes, they include an asymptomatic carrier, ARD, and pneumonia of varying degrees of severity. However, the first asymptomatic cases were diagnosed based on positive viral nucleic acid test results, without any early COVID-19 symptoms, such as fever, gastrointestinal and respiratory symptoms, as well as no significant abnormalities on pulmonary radiograph $(9,10)$.

The widespread of the disease with a corresponding daily increase in the number of confirmed cases and deaths globally have inspired the urgent quest for antiviral drugs to curb the menace. Several attempts are being made to treat and reduce severe infections. Chloroquine and other antiviral drugs which have been used globally for decades as an antimalarial drug and treatment of previous cases of viral infection respectively, and are enlisted as part of the WHO model list of potential medicines, have been suggested as potential candidates against the spread of the disease, however, their efficacy and safety concerns remain unclear $(11,12)$. Also, the virtual screening and repurposing of some drugs such as Chromocarb, Ribavirin, Telbivudine, Vitamin B12, etc. approved by the Food and Drug Administrations (FDA), show a high docking score and high ligand efficiency and can be used to inhibit the COVID-19 main protease $(13,14)$. Cortegiani et al. carried out a study using PubMed, EMBASE, and three trial registries to identify studies on the use of chloroquine in patients with COVID-19. The authors were able to unravel one narrative letter, one in-vitro study, one editorial, expert consensus paper, two national guideline documents, and 23 ongoing clinical trials. Early investigations inferred that chloroquine derivatives seem to be effective in limiting the replication of SARS-CoV-2 (the virus causing COVID-19) in vitro (15). Some other studies have proposed the efficacy of a single drug or combined drug therapy of Remdesivir, Lopinavir /Ritonavir, Favipiravir since they can interfere with the synthesis of viral mRNA targeting RdRp $(16,17)$.

Experimental research is currently in top gear on the use of various antibiotics and antiviral agents, especially in combined therapy as a possible vaccine for COVID-19 (18). Herein, we project the potency of the combined therapy of encapsulating the clinical trial drugs with biocompatible and biodegradable chitosan (a biopolymeric cationic molecule with free $\mathrm{OH}$ and $\mathrm{NH}$ groups) as a potential drug delivery agent for COVID-19.
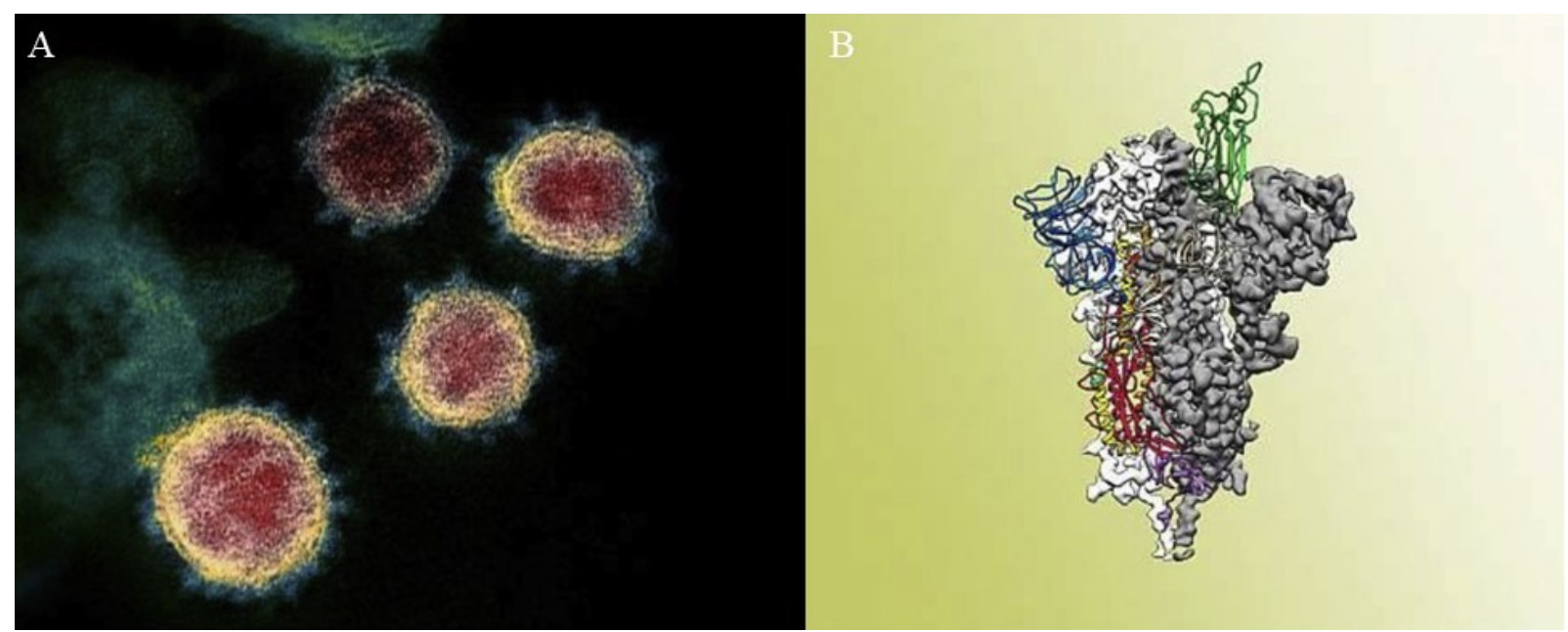

Figure 1. (A) The spikes on the outer edge of the virus particles give coronaviruses their name, crownlike, TEM image (B) Atomic-level structure of the SARS-CoV-2 spike protein. Reproduced with permission from Ref. (3). Copyright 2020 IMSS (Elsevier Inc.). 


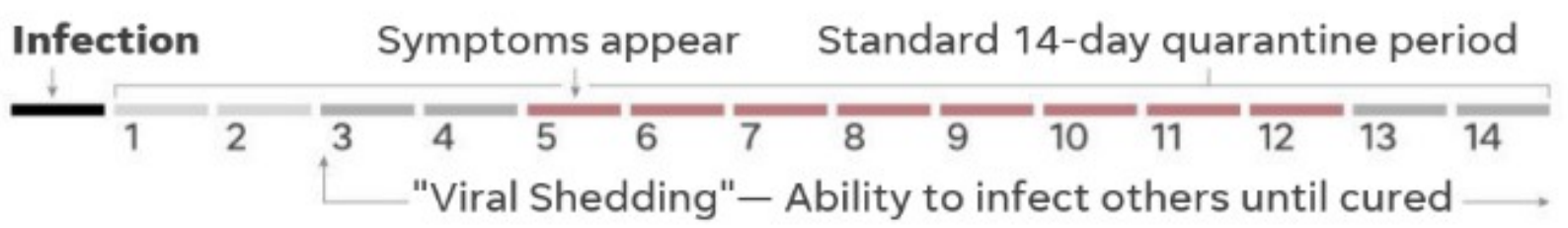

Figure 2. Incubation period of COVID-19 after an initial period of exposure to the virus to quarantine period. Reproduced from Ref. (8). Copyright USA Today.

\section{MODE OF ACTION OF COVID-19}

Coronaviruses (SARS-CoV) are single-stranded RNA viruses belonging to the family Coronaviridae, which can cause various diseases with enteric, respiratory, hepatic, and neurological symptoms with mild to serious infections in birds and mammals (19). Under an electron microscope, the coronaviruses were observed to be protruding to the periphery with a diameter of $60-160 \mathrm{~nm}$. Each particle is enveloped containing a single-stranded positive-sense RNA (+ssRNA) genome of 27-32 kb with 5'-cap structure and $3^{\prime}$-poly A tail which interacts with the nucleoprotein (20). Thus, when the virus finds its way into the host, it infects the cells by binding to the angiotensin-converting enzyme 2 (ACE2) receptor on the surface of the cell through its envelope-spike glycoprotein domain (21-23).

The entry of SARS-CoV into cells was initially identified to be accomplished by direct membrane fusion between the virus and plasma membrane. Therefore, once inside the cells, the viral RNA genome is released into the cytoplasm and is translated into two polyproteins and structural proteins, after which the viral genome begins to replicate (see Figure 3) (24). The newly formed envelope glycoproteins are inserted into the membrane of the endoplasmic reticulum or Golgi, and the nucleocapsid is formed by the combination of genomic RNA and nucleocapsid protein. Then, viral particles germinate into the endoplasmic reticulum-Golgi intermediate compartment (ERGIC) (25). Eventually, the vesicles containing the virus particles fuse with the plasma membrane to release the virus (23).

Presently, nucleic acid testing and computed tomography (CT) scans are being used to diagnose and screen possible COVID-19 infected patients, with a number of reverse transcription polymerase chain reaction ( $R T-P C R$ ) kits been designed to detect SARS-CoV-2 based on genes, with CT scans which involves many X-ray measurements taken at different angles at infected person's pulmonary region, are both used for accurate diagnoses as they can target as well as identify the specific viral agent (26-29).

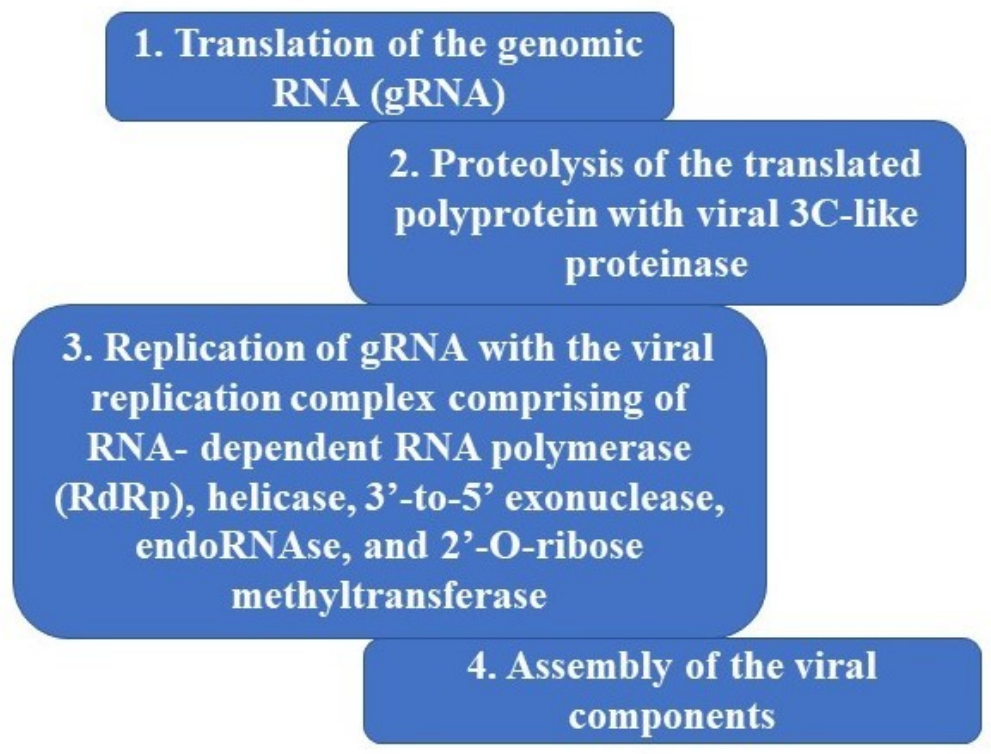

Figure 3. Replication processes involved in the life cycle of the coronavirus after entering the host cell. Adapted from Ref. (30,31) Copyright 2020 CC-BY-NC-ND 4.0 International license and 2015 Elsevier B.V. 


\section{ANTIVIRAL AGENTS FOR COVID-19}

Chloroquine (see Figure 4a), also known as Resochin is a weak base that was first extracted from the bark of cinchona tree which had been used to treat fever and malaria. This compound, which is an amine acidotropic form of quinine is a lysosomotropic agent with rapid rate of absorption and distribution in bodily tissues; its metabolism is partially hepatic, giving rise to its main metabolite, desethylchloroquine and easily excreted in urine (32). Hydroxychloroquine (see Figure 4b) is the main derivative of chloroquine which differs by the presence of a hydroxyl group at the end of the side chain: the $\mathrm{N}$-ethyl substituent is $\beta$-hydroxylated (33). Over the years, chloroquine and its derivatives have been used to treat autoimmune diseases, such as amebiasis that is occurring outside the intestines, rheumatoid arthritis, and systemic lupus erythematosus (34). More so, the sulfate and phosphate salts (see Figure 4c) of chloroquine have both been commercialized as antimalarial drugs (35). For example, Kashyap et al. formulated dextran nanoparticles bearing chloroquine diphosphate by solvent diffusion method yielding particle size below $70 \mathrm{~nm}$ with zeta-potential of $-20.1 \pm 3.2 \mathrm{mV}$. This was successfully used for drug delivery and overwhelmed drug resistance in Plasmodium falciparum parasites (36).

Studies have shown that chloroquine or its derivatives possess a broad spectrum of antiviral effects as potent inhibitors on a variety of viruses including the Ebola virus, Zika virus, and SARSCoV-1, etc. (37-39). They are deployed as an antiviral drug because it can affect virus infection in many ways depending on the part and extent to which the virus utilizes endosomes for entry (37). Thus, they can inhibit the in vitro replication of viruses which envelope and fuses with that of the acidified endosome (40), since the structure and mechanism of action is via acting as a weak base that can change the $\mathrm{pH}$ of acidic intracellular organelles including endosomes/lysosomes, essential for the membrane fusion $(41,42)$. Additionally, since SARS-CoV-2 utilizes the similar surface receptor ACE2, it is believed that chloroquine can also interfere with ACE2 receptor glycosylation and prevents SARS-CoV-2 attachment to the target cells $(43,44)$ The clinical safety profile of hydroxychloroquine is better compared with that of chloroquine (during longterm use) and allows higher daily dose with fewer concerns regarding drug-drug interactions (45). It also shows a high partitioning in tissue, including lung and brain, thus, offering a key clinical advantage in the case of COVID-19 (46).

Preliminary results from a small trial suggest that a combination of hydroxychloroquine and azithromycin is efficacious for reducing the viral load in patients with COVID-19 as tested on a 72year-old woman admitted to a non-telemetry floor with a cohort of other COVID-19 patients (47). Meanwhile, Gautret et al. iterated that hydroxychloroquine treatment is significantly associated with viral load reduction/disappearance in COVID-19 patients and its effect is reinforced by azithromycin after an extensive study on 22 cases in France (48). Apart from chloroquine and derivatives, other therapeutic drugs reported for treating viral-related cases are listed in Table 1.<smiles>CCN(CC)CCC(C)Nc1ccnc2cc(Cl)ccc12</smiles><smiles>[X][R5]Oc1ccc(NC(C)CCN(CC)CO)c2ccc(Cl)cc12</smiles>

C

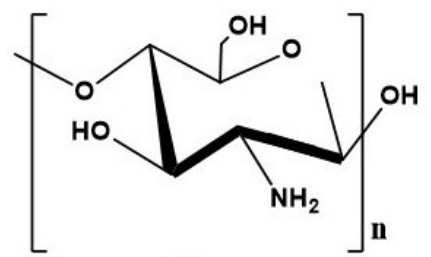

D

Figure 4. Structural formula of (A) chloroquine (B) hydroxychloroquine (C) hydroxychloroquine sulfate/phosphate (D) chitosan. 
Table 1 Other therapeutic prospective antiviral drugs/treatments.

\begin{tabular}{|c|c|c|c|c|}
\hline Drug & Chemical formula & Class of drug & Target & Ref. \\
\hline Remdesivir & $\mathrm{C}_{27} \mathrm{H}_{35} \mathrm{~N}_{6} \mathrm{O}_{8} \mathrm{P}$ & $\begin{array}{l}\text { Adenosine } \\
\text { analogue }\end{array}$ & Viral RNA chains & $(49)$ \\
\hline $\begin{array}{l}\text { Lopinavir } \\
\text { / Ritonavir }\end{array}$ & $\begin{array}{l}\mathrm{C}_{37} \mathrm{H}_{48} \mathrm{~N}_{4} \mathrm{O}_{5} / \\
\mathrm{C}_{37} \mathrm{H}_{48} \mathrm{~N}_{6} \mathrm{O}_{5} \mathrm{~S}_{2}\end{array}$ & $\begin{array}{l}\text { Protease } \\
\text { inhibitors }\end{array}$ & $\begin{array}{l}\text { HIV protease enzymes, SARS } \\
\text { associated coronavirus }\end{array}$ & $(50,51)$ \\
\hline Favipiravir & $\mathrm{C}_{5} \mathrm{H}_{4} \mathrm{FN}_{3} \mathrm{O}_{2}$ & $\begin{array}{l}\text { Prodrug anti- } \\
\text { influenza }\end{array}$ & $\begin{array}{l}\text { Viral RNA-dependent RNA } \\
\text { polymerase }\end{array}$ & $(52)$ \\
\hline Ribavirin & $\mathrm{C}_{8} \mathrm{H}_{12} \mathrm{~N}_{4} \mathrm{O}_{5}$ & $\begin{array}{l}\text { Guanosine } \\
\text { (ribonucleic) } \\
\text { analog }\end{array}$ & $\begin{array}{l}\text { Viral RNA synthesis and viral } \\
\text { mRNA capping }\end{array}$ & $(53,54)$ \\
\hline Sofosbuvir & $\mathrm{C}_{22} \mathrm{H}_{29} \mathrm{FN}_{3} \mathrm{O}_{9} \mathrm{P}$ & $\begin{array}{l}\mathrm{HCV} \text { polymerase } \\
\text { inhibitor }\end{array}$ & Inhibitor of viral RNA synthesis & \\
\hline Galidesivir & $\mathrm{C}_{11} \mathrm{H}_{15} \mathrm{~N}_{5} \mathrm{O}_{3}$ & Nucleoside analog & $\begin{array}{l}\text { Broad-spectrum of RNA virus } \\
\text { families }\end{array}$ & \\
\hline Tenofovir & $\mathrm{C}_{19} \mathrm{H}_{30} \mathrm{~N}_{5} \mathrm{O}_{10} \mathrm{P}$ & $\begin{array}{l}\text { Antiretroviral } \\
\text { prodrug }\end{array}$ & $\begin{array}{ll}\text { Nucleotide } & \text { reverse } \\
\text { transcriptase inhibitor } & \\
\end{array}$ & \\
\hline Triazavirin & $\mathrm{C}_{5} \mathrm{H}_{4} \mathrm{~N}_{6} \mathrm{O}_{3} \mathrm{~S}$ & $\begin{array}{l}\text { Non-nucleoside } \\
\text { antiviral drugs }\end{array}$ & Influenza strains such as H5N1 & \\
\hline Teicoplanin & $\mathrm{C}_{88} \mathrm{H}_{97} \mathrm{Cl}_{2} \mathrm{~N}_{9} \mathrm{O}_{33}$ & $\begin{array}{l}\text { Glycopeptide } \\
\text { antibiotic }\end{array}$ & Viral spike protein & $(55)$ \\
\hline Atazanavir & $\mathrm{C}_{38} \mathrm{H}_{52} \mathrm{~N}_{6} \mathrm{O}_{7}$ & Protease inhibitor & Active viral proteins & $(30)$ \\
\hline Interferons & & $\begin{array}{l}\text { Signaling proteins } \\
\text { (cytokines) }\end{array}$ & Viral infections & $(56,57)$ \\
\hline $\begin{array}{l}\text { Convalescent } \\
\text { plasma }\end{array}$ & & Antibody titer & $\begin{array}{l}\text { Inhibiting the formation of } \\
\text { inflammatory } \\
\text { cytokine storms }\end{array}$ & $(58,59)$ \\
\hline
\end{tabular}

\section{CHITOSAN-ENCAPSULATED DRUG AS DRUG DELIVERY VEHICLES}

Chitosan (see Figure 4d) is a naturally occurring polysaccharide that has attracted lots of scientific interest over the years especially in the aspect of drug delivery systems which is considered to be a hopeful and viable strategy for improving infectious disease treatment (60). Chitosan is a biodegradable and biocompatible deacetylated derivative of chitin made up of randomly distributed $\quad \beta$ - $(1 \rightarrow \quad 4)$-2-amino-2-deoxy-Dglucopyranose which have been extensively exploited in bio-medical applications (61-63). The antimicrobial activity of chitosan has been extensively observed against a wide variety of microorganisms including fungal, algal, and bacterial strains (64-66). This has been achieved by taking advantage of the cationic charge and hydrogen bonding ability to stabilize biological structures such as DNA, RNA, and proteins in biological systems (67). Also, the higher antibacterial activity of chitosan over other types of disinfectants is demonstrated in its ability to chelate with metal ions to form new compounds and lower toxicity towards mammalian cells (68).

The skeletal framework of chitosan is made of free hydroxy and amine groups which can easily hydrogen-bond with other molecules, while the free amine groups can be protonated in acidic medium and ionically bind with the reactive sulfate or phosphate groups of the drug molecules (see Table 1) via an encapsulation strategy to form new compounds (see Figure 5) (30). Therefore, this cationic biopolymer can act as an effective viral drug delivery agent since it can enhance the loading efficiency of DNA/RNA binding electrostatically, thereby reduces the rate of diffusion and promoting a more sustained release to target sites $(69,70)$. Additionally, the existence of the outer polymer encapsulate could protect the DNA/RNA from innate biological degradation systems allowing more-effective transport across the cellular membrane to reach the target site in the nucleus (see Figure 6) (71). Apart from the successful encapsulation of chitosan for enhanced drug delivery (72), chitosan and its derivatives have been successfully utilized in vitro and in vivo for DNA and siRNA delivery systems because of their cationic charge, biodegradability and biocompatibility, as well as mucoadhesive, and permeability-enhancing properties (73). Additionally, the encapsulation of chitosan with other bulk- or nano-materials have been achieved for the effective delivery of gene (74), nucleic acid, (75) and as a non-viral vector in different clinical applications. 


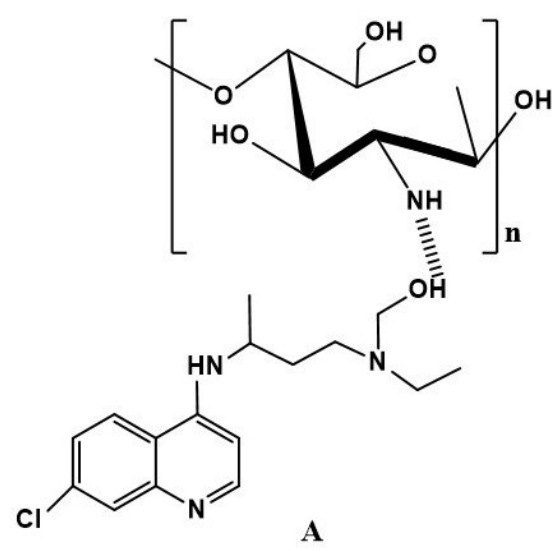

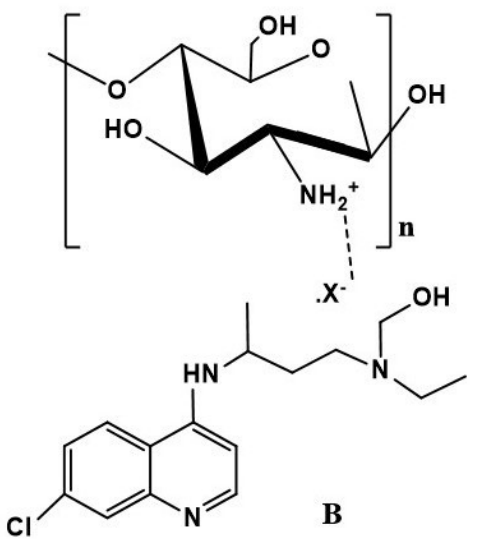

Figure 5. Possible interaction between chitosan and chloroquine or other drug molecules via (A) hydrogen bonding (B) ionic bonding with the available $\mathrm{OH}$ or ionic group in the drug's skeletal framework.

Existing studies have reported the efficacy of chitosan-tripolyphosphate conjugated chloroquine nanoparticle as an in vivo anti-malarial and antioxidant agent (76). For example, Magalhães et al. prepared chitosan (polycationic)/Sterculia striata (polyanionic) polysaccharides nanocomplex by polyelectrolyte complexation method and subsequently employed as a potential chloroquine drug release agent (77). Also, polymeric based iron nano-chloroquine phosphate was designed to encapsulate drug molecule for the delayed or slow release of drug in biological systems (78). These studies clearly show the potency of the nanodrug delivery technology as a more prospective treatments strategy than using only chloroquine or its derivatives alone to combat the parasite infection, oxidative stress as well as inflammation and DNA/RNA damage (60). However, using a combination of structural and molecular modeling approaches, Fantini et al. was able to show that chloroquine, which is one of the drugs currently under investigation for SARS-CoV-2 treatment, could bind sialic acids and gangliosides with high affinity. Thus, the team identified a new type of ganglioside-binding domain at the tip of the $\mathrm{N}$ terminal domain of the SARS-CoV-2 spike (S) protein. This domain (aa 111-158), which is fully conserved among clinical isolates worldwide, may improve the attachment of the virus to lipid rafts and facilitate the contact with the ACE2 receptor, with an inference that in the presence of chloroquine or its derivate, the viral spike is no longer able to bind gangliosides (79). Moreover, hydroxychloroquine, being less toxic, has an $\mathrm{N}$ hydroxyethyl side chain in place of the $\mathrm{N}$-diethyl group of chloroquine. This modification makes hydroxychloroquine more soluble than chloroquine, making it more open for easy attachment with other compounds like chitosan. In the same vein, hydroxychloroquine encapsulated chitosan increases the $\mathrm{pH}$ and could confer antiviral effects (80), thereby offering a modulating effect on activated immune cells and altering the glycosylation of the cellular receptors of coronaviruses $(81,82)$. Furthermore, very limited studies have reported the encapsulation of other viral drugs on polymeric substrates as drug delivery vehicles to target sites. The success of Ravi et al. on the oral delivery of Lopinavir loaded nanoparticles on a hydrophobic derivative of pullulan acetate with a nanoparticle size distribution of $\sim 197 \mathrm{~nm}$, high entrapment efficiency $(\sim 75 \%)$, monodispersive nature (PDI < 0.2 ) and stability for 3 months opens promising adventure for higher encapsulated drug delivery than a drug-free system (83). 

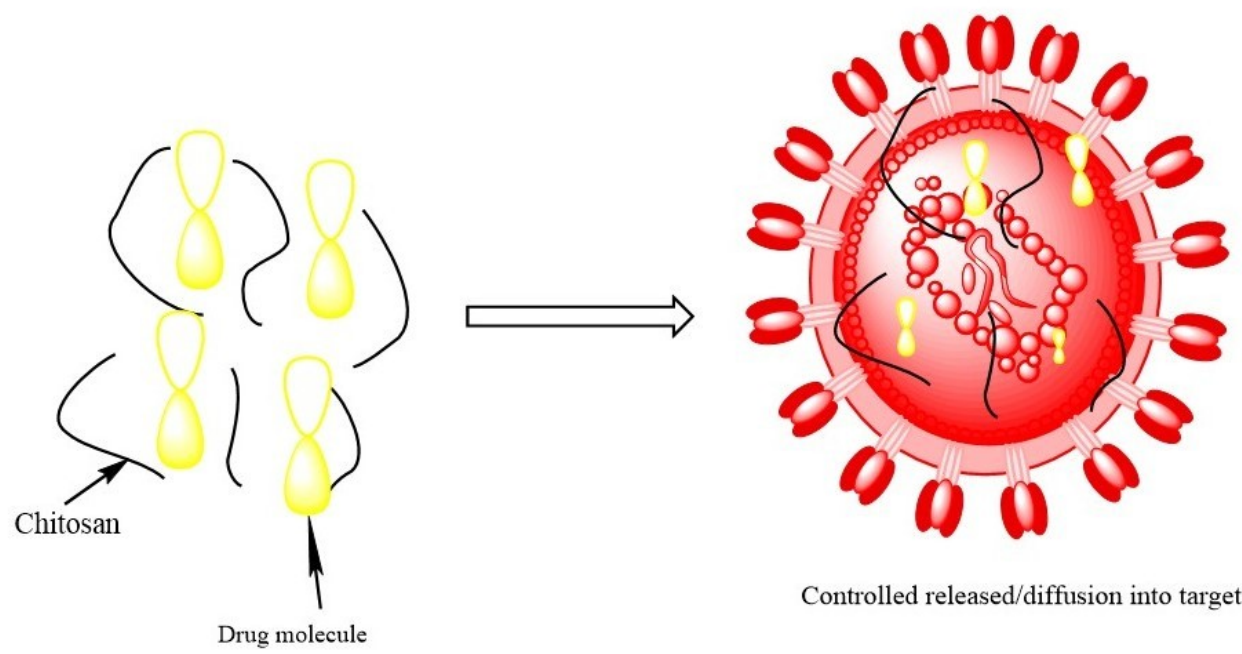

Controlled released/diffusion into target site

Figure 6. Controlled release of chitosan encapsulated drug and diffusion into the target site in the nucleus of the host.

\section{Delivery of Chitosan Loaded Anti-Viral Drugs/ Vaccines}

Antiviral drugs, either target specific or broadspectrum are a class of drug molecules used for treating viral infections or inhibiting the development of a viral pathogen. Studies have shown that the pharmacokinetics of Triazavirin, $\mathrm{C}_{5} \mathrm{H}_{4} \mathrm{~N}_{6} \mathrm{O}_{3} \mathrm{~S}$, can be improved via encapsulation with amino acids and quaternary amine compounds. Thus, Kozhikhova et al. (84) reported the stability and high mucoadhesive activity of charged liposome with modified chitosan coating as a nanocarrier for the delivery of Triazavirin via an underlying interaction between liposomes surface, positive chitosan coating, and negatively charged mucin secreted from epithelial cells, while Cánepa et al. (85) reported a novel chitosan-based nanocarrier for the oral delivery of interferon-a (IFNa-2b) prepared by ionotropic gelation and encapsulating approximately $100 \%$ of the drug, with the antiviral potency of the nanocarrier showing maximum inhibitory efficiency against Human Lymphotropic-T Virus type 1 at 0.3 MIU to CF1 in mice. Also, Donalisio et al. (86) formulated chitosan nanosphere via a modified nanoemulsive template method for the delivery of acyclovir into Vero cell line infected with Herpesviruses, HSV-1, and HSV-2 strains. The acyclovir-loaded chitosan nanosphere displayed remarkable antiviral activity with no anti-proliferative activity, no signs of cytotoxicity and a drug loading capacity was recorded to be about $8.5 \%$ with an in vitro release of approximately $30 \%$ after $6 \mathrm{~h}$. Additionally, Ulla et al. (87) examined the morphology and drug loading performance of a copolymerized chitosan and starch nanohydrogel functionalized with phthalic-anhydride and hexamethylenetetramine via 1-ethyl-3-(3-dimethylaminopropyl) carbodiimide catalyzed coupling, respectively. The promising antiviral and antimicrobial agents with flexible and biocompatible functionalities revealed an increased drug loading efficiency from $65 \%$ to 80 and $85 \%$ for hydrophobic- anionic drugs. Furthermore, a novel nanoparticulate system for based on foscarnet-chitosan nanoparticles was prepared by Russo et al. (88) for the delivery of foscarnet (antiviral agent for herpesvirus DNA polymerase). It was reported that the foscarnet released from nanoparticles was non-toxic and also maintained the antiviral activity of the free drug when tested in vitro against lung fibroblasts (HELF) cells infected with HCMV strain AD-169.

In an attempt to improve the antiviral effectiveness of nucleoside reverse transcriptase inhibitors (NRTIs) and lessen possible side effects, Yang et al. (89) developed a novel nanosized water-soluble chitosan-O-isopropyl-5'-0-d4T monophosphate conjugate. The in vitro drug release studies of the conjugate system at $\mathrm{pH} 1.1$ and $\mathrm{pH} 7.4$ in MT4 cell line show outstanding antiHIV effect and low cytotoxicity. Yan et al. (90) explored the potentials of nanosized polyelectrolyte (PEC) complexes constructed by simple mixing of negatively charged curdlan sulfate (CRDS) into positively charged chitosan in aqueous solutions. The spherical PEC with negative zeta potential (-38 $\mathrm{mV}$ ) were successfully loaded into zidovudine (an antiretroviral medication) and exhibited favorable drug loading efficiency at controlled $\mathrm{pH}$. On another hand, Cazorla-Luna et al. (91) reported as-prepared chitosan-based mucoadhesive vaginal tablets in combination with pectin and locust bean gum, for the sustained release of tenofovir against HIV infection. The obtained results show that the tablet's formulation containing chitosan/pectin has the most homogeneous tenofovir dissolution profiles and stayed attached to the vaginal mucosa for up to $96 \mathrm{~h}$, hence a promising self-protection choice for women against sexually-transmitted 
HIV. Furthermore, Wu et al. (92) investigated the nanocomplexation of polyelectrolytes comprising of chitosan, chondroitin sulfate, and zinc(II) ions followed by encapsulation onto tenofovir, with the study revealing that the nanoparticles were noncytotoxic to human peripheral blood mononuclear cells and could reduce HIV-1 infection with an inhibitory concentration, IC $_{50}$ of 4.35 $\mu \mathrm{mol} \cdot \mathrm{L}^{-1}$ to $1.95 \mu \mathrm{mol} \cdot \mathrm{L}^{-1}$ when employed as drug carriers.

Vaccination is the most effective method of inhibiting and controlling viral infections. Viral infections can be mainly categorized into three based on the infection nature, namely: (a) acute infections caused by antigenically stable viruses, e.g. yellow fever, measles, mumps; (b) acute infections caused by rapidly mutating viruses e.g. influenza; and (c) chronic infections such as HIV and HCV. (93-95) Antiviral vaccines, on the other hand, are biological preparations containing an agent that mimics the viral pathogen, offering an active acquired immunity to a specific viral infection. Biopolymeric chitosan has shown the potentials of augmenting the immune responses with established safety and nontoxicity record in animals and humans as a vaccine against respiratory syncytial virus (RSV) infection (96). Spinner et al. (97) examined the sublingual vaccination of mice with split-flu vaccine formulated with methylglycol chitosan (MGC) and synthetic toll-like receptor 4 agonist (CRX-601) alone or in combination. The obtained results revealed that MGC and/or CRX-601 adjuvanted split-flu vaccines administered sublingually prompted a better mucosal and a corresponding systemic immune response to flu vaccine when delivered intramuscularly. Also, an adjuvanted influenza chitosan nanovaccine based on poly(I:C) could induce the proliferation of antigen-specific IFNY secreting T-helper/memory and $\mathrm{Y} \delta \mathrm{T}$ cells, have been developed and tested in young swine against swine influenza virus (98). In another approach, El-Sissi et al. (99) prepared an adjuvanted vaccine formulation based on chitosan (CS) or chitosan nanoparticles (CNP, prepared by ionic gelation technique) loaded with Rift Valley Fever Virus (RVFV) inactivated antigen. These formulations were observed to be superior to the RVFV-Alum vaccine as the former strongly boosted the phagocytic activity of peritoneal macrophage, neutralization of antibodies titer against RVFV and IgG values against RVFV nucleoprotein.

\section{CONCLUSION}

Chitosan is an abundant natural biopolymer that has been effective as an anti-microbial agent and has been successfully applied for the treatment of many ailments. Studies have shown that its effective application as a non-viral carrier for gene delivery, nucleic acid, and drug delivery systems. The cationic biopolymer possesses free hydroxyl and amine functional groups that can easily be encapsulated to the existing antiviral agents via electrostatic interaction or hydrogen bonding to form new compounds with milder side effects and enhanced ability to be delivered to the target sites. The numerous binding sites and chelating ability of the polymer may also be exploited for the fabrication of organometallic complexes, coordination compounds, and nanocomposites for possible deployment as an effective drug delivery agent against the deadly COVID-19.

\section{ACKNOWLEDGMENTS}

This work is supported by the Chinese Scholarship Council.

\section{CONFLICTS OF INTEREST}

The authors hereby declare no conflicting interest.

\section{AUTHORS' CONTRIBUTIONS}

Onome Ejeromedoghene: Conceptualization, writing - original draft preparation, Funding acquisition; Olayinka Oderinde: Writing - original draft preparation, Funding acquisition; George Egejuru: Writing - review and editing; Sheriff Adewuyi: Supervision, critical review and editing.

\section{REFERENCES}

1. Fang L, Karakiulakis $G$, Roth $M$. Antihypertensive drugs and risk of COVID-19? Authors' reply. Lancet Respir Med [Internet] Elsevier Ltd; 2020;2600(20):19-20. Available from: http://dx.doi.org/10.1016/S22132600(20)30159-4

2. Wu F, Zhao S, Yu B, et al. A new coronavirus associated with human respiratory disease in China. Nature 2020;579(7798):265-9.

3. Das UN. Can Bioactive Lipids Inactivate Coronavirus (COVID-19)? Arch Med Res [Internet] Elsevier Inc; 2020; Available from: https://doi.org/ 10.1016/j.arcmed.2020.03.004

4. Mackenzie JS, Smith DW. COVID-19: a novel zoonotic disease caused by a coronavirus from China: what we know and what we don't. Microbiol Aust 2020;

5. Yang $Y$, Peng $F$, Wang $R$, et al. The deadly coronaviruses: The 2003 SARS pandemic and the 2020 novel coronavirus epidemic in China. J Autoimmun [Internet] Elsevier; 2020;102434. Available from:

https://doi.org/10.1016/j.jaut.2020.102434 
6. McCuaig C. What We Know So Far (As of March 26, 2020) About COVID-19 - An MRT Point of View. J Med Imaging Radiat Sci [Internet] Canadian Association of Medical Radiation Technologists; 2020; Available from: http://www.sciencedirect.com/science/article/pii/S 1939865420300394

7. Driggin E, Madhavan M V., Bikdeli B, et al. Cardiovascular Considerations for Patients, Health Care Workers, and Health Systems During the Coronavirus Disease 2019 (COVID-19) Pandemic. J Am Coll Cardiol [Internet] American College of Cardiology Foundation; $2020 ; 2019$. Available from: https://doi.org/10.1016/j.jacc.2020.03.031

8. Zarracina J, Rodriguez A. A visual guide of coronavirus infection, symptoms of COVID-19 and the effects of the virus inside the body, in graphics. USA Today [Internet] 2020 Mar 17; Available from: https://www.usatoday.com/indepth/news/2020/03/13/what-coronavirus-doesbody-covid-19-infection-process-symptoms/ 5009057002/

9. Yan Bai, Yao L, Wei T, et al. Presumed Asymptomatic Carrier Transmission of COVID-19. letters 2020;382(13):1199-207.

10. Lai CC, Liu YH, Wang CY, et al. Asymptomatic carrier state, acute respiratory disease, and pneumonia due to severe acute respiratory syndrome coronavirus 2 (SARS-CoV-2): Facts and myths. $J$ Microbiol Immunol Infect [Internet] Elsevier Taiwan LLC; 2020;2(xxxx). Available from:

https://doi.org/10.1016/j.jmii.2020.02.012

11. World Health Organization (WHO). What is the WHO position on the use of chloroquine and hydroxylchloroquine in the context of the COVID19 response? [Internet]. 2020 [cited 2020 Apr 13]. Available from:

https://www.who.int/news-room/q-a-detail/malari a-and-the-covid-19-pandemic

12. World Health Organization. 19th WHO Model List of Essential Medicines. Http://WwwWhoInt/Medicines/Publications/Essenti almedicines/En [Internet] 2015;1-43. Available from: http://www.who.int/medicines/organization/ par/edl/expcom13/eml13\%7B_\%7Den.pdf

13. Kandeel M, Al-Nazawi M. Virtual screening and repurposing of FDA approved drugs against COVID-19 main protease. Life Sci [Internet] Elsevier; 2020;251:117627. Available from: https://doi.org/10.1016/j.Ifs.2020.117627

14. Smith T, Bushek J, LeClaire A, Prosser T.
COVID-19 Drug Therapy. Elsevier - Nov

Coronavirus Inf Cent [Internet] 2020;(CDC):1-21. Available from: https://www.elsevier.com/connect/ coronavirus-information-center\# research

15. Cortegiani $A$, Ingoglia $G$, Ippolito $M$, Giarratano A, Einav S. A systematic review on the efficacy and safety of chloroquine for the treatment of COVID-19. J Crit Care [Internet] Elsevier Inc. ; 2020;3-7. Available from:

https://doi.org/10.1016/j.jcrc.2020.03.005

16. Duan $\mathrm{Y}$, Zhu H-L, Zhou C. Advance of promising targets and agents against 2019-nCoV in China. Drug Discov Today [Internet] Elsevier Ltd; 2020;00(00):10-2. Available from: https://doi.org/10.1016/j.drudis.2020.02.011

17. Choy K-T, Yin-Lam Wong A, Kaewpreedee $P$, et al. Remdesivir, lopinavir, emetine, and homoharringtonine inhibit SARS-CoV-2 replication in vitro. Antiviral Res [Internet] Elsevier B.V.; 2020;104786. Available from: http://www.ncbi.nlm.nih.gov/pubmed/32251767

18. Smereka J, Szarpak L. COVID 19 a challenge for emergency medicine and every health care professional. Am J Emerg Med 2020; $(x x x x): 2-3$.

19. Lim $\mathrm{YX}, \mathrm{Ng} \mathrm{YL}$, Tam JP, Liu DX. Human Coronaviruses: A Review of Virus - Host Interactions. Diseases 2016;4(26):1-28.

20. Kang S, Peng W, Zhu Y, et al. Recent Progress in understanding 2019 Novel Coronavirus associated with Human Respiratory Disease: Detection, Mechanism and Treatment. Int J Antimicrob Agents [Internet] Elsevier B.V.; 2020;105950. Available from:

https://doi.org/10.1016/j.ijantimicag.2020.105950

21. Wu C-I, Postema PG, Arbelo E, et al. SARS-CoV-2, COVID-19 and inherited arrhythmia syndromes. Hear Rhythm [Internet] Heart Rhythm Society; 2020; Available from:

http://www.sciencedirect.com/science/article/pii/S $154752712030285 \mathrm{X}$

22. Simmons G, Reeves JD, Rennekamp AJ, Amberg SM, Piefer AJ, Bates P. Characterization of severe acute respiratory syndrome-associated coronavirus (SARS-CoV) spike glycoproteinmediated viral entry. Proc Natl Acad Sci U S A 2004;101(12):4240-5.

23. De Wit E, Van Doremalen N, Falzarano D, Munster VJ. SARS and MERS: Recent insights into emerging coronaviruses. Nat Rev Microbiol [Internet] Nature Publishing Group; 2016;14(8):523-34. Available from: 
Ejeromedoghene O et al. JOTCSA. 2020; 7(3): 851-864.

http://dx.doi.org/10.1038/nrmicro.2016.81

24. Perlman S, Netland J. Coronaviruses postSARS: Update on replication and pathogenesis. Nat Rev Microbiol 2009;7(6):439-50.

25. Li X, Geng M, Peng Y, Meng L, Lu S. Molecular immune pathogenesis and diagnosis of COVID-19. J Pharm Anal [Internet] Elsevier Ltd; 2020;19(xxxx):1-7. Available from: https://doi.org/10.1016/j.jpha.2020.03.001

26. Udugama B, Kadhiresan P, Kozlowski HN, et al. Diagnosing COVID-19: The Disease and Tools for Detection. ACS Nano 2020;

27. Kageyama T, Kojima S, Shinohara M, et al. Broadly reactive and highly sensitive assay for Norwalk-like viruses based on real-time quantitative reverse transcription-PCR. J Clin Microbiol 2003;41(4):1548-57.

28. Lee EYP, Ng MY, Khong PL. COVID-19 pneumonia: what has CT taught us? Lancet Infect Dis Elsevier Ltd; 2020;20(4):384-5.

29. Bernheim A, Mei X, Huang M, et al. Chest CT Findings in Coronavirus Disease-19 (COVID19): Relationship to Duration of Infection. Radiology 2020;1-8.

30. Beck BR, Shin B, Choi Y, Park S, Kang K. Predicting commercially available antiviral drugs that may act on the novel coronavirus (2019nCoV), Wuhan, China through a drug-target interaction deep learning model. bioRxiv [Internet] The Authors; 2020;18:2020.01.31.929547. Available from: https://www.biorxiv.org/content/biorxiv/early/202 0/02/02/2020.01.31.929547.full.pdf

31. Fung TS, Liu DX. Human Coronavirus: Host-Pathogen Interaction. Annu Rev Microbiol 2019;73(1).

32. Srivastava V, Lee H. Chloroquine-based hybrid molecules as promising novel chemotherapeutic agents. Eur J Pharmacol [Internet] Elsevier; 2015;762:472-86. Available from:

http://dx.doi.org/10.1016/j.ejphar.2015.04.048

33. Devaux CA, Rolain J-M, Colson P, Raoult D. New insights on the antiviral effects of chloroquine against coronavirus: what to expect for COVID-19? Int J Antimicrob Agents [Internet] Elsevier B.V.; $2020 ; 105938$. Available from:

https://doi.org/10.1016/j.ijantimicag.2020.105938

34. Zhang W, Zhao Y, Zhang $F$, et al. The use of anti-inflammatory drugs in the treatment of people with severe coronavirus disease 2019

(COVID-19): The experience of clinical immunologists from China. Clin Immunol

[Internet] Elsevier; 2020;214:108393. Available from: https://doi.org/10.1016/j.clim.2020.108393

35. Touret F, de Lamballerie $X$. Of chloroquine and COVID-19. Antiviral Res [Internet] Elsevier; 2020;177:104762. Available from: https://doi.org/ 10.1016/j.antiviral.2020.104762

36. Kashyap A, Kaur R, Baldi A, Kumar U, Chandra R, Madan J. Chloroquine diphosphate bearing dextran nanoparticles augmented drug delivery and overwhelmed drug resistance in Plasmodium falciparum parasites. Int $\mathrm{J}$ Biol Macromol [Internet] Elsevier B.V.; 2018;114:1618. Available from:

https://doi.org/10.1016/j.ijbiomac.2018.03.102

37. Vincent MJ, Bergeron E, Benjannet S, et al. Chloroquine is a potent inhibitor of SARS coronavirus infection and spread. Virol J 2005; 10:1-10.

38. Barnard DL, Day CW, Bailey K, et al. Evaluation of immunomodulators, interferons and known in vitro SARS-CoV inhibitors for inhibition of SARS-CoV replication in BALB / c mice. Antivir Chem Chemother 2006;275-84.

39. Akpovwa H. Chloroquine could be used for the treatment of filoviral infections and other viral infections that emerge or emerged from viruses requiring an acidic $\mathrm{pH}$ for infectivity. Cell Biochem Funct $2016 ; 191-6$.

40. Lecuit M. Chloroquine and COVID-19, where do we stand? Médecine Mal Infect [Internet] Elsevier Masson SAS; 2020;3-4. Available from: https://doi.org/10.1016/j.medmal.2020.03.004

41. Colson P, Rolain JM, Lagier JC, Brouqui P, Raoult D. Chloroquine and hydroxychloroquine as available weapons to fight COVID-19. Int J Antimicrob Agents [Internet] Elsevier B.V.; 2020; $(x x x x): 105932$. Available from: https://doi.org/10.1016/j.ijantimicag.2020.105932

42. Singh AK, Singh A, Shaikh A, Singh R, Misra $A$. Chloroquine and hydroxychloroquine in the treatment of COVID-19 with or without diabetes: A systematic search and a narrative review with a special reference to India and other developing countries. Diabetes Metab Syndr Clin Res Rev [Internet] Elsevier Ltd; 2020;14(3):2416. Available from: https://doi.org/10.1016/j.dsx.2020.03.011

43. Colson $\mathrm{P}$, Rolain J-M, Raoult D. Chloroquine for the 2019 novel coronavirus. Int J Antimicrob 
Agents [Internet] Elsevier B.V.; 2020;105923. Available from: https://doi.org/10.1016/j.ijantimicag.2020.105923

44. Lu H. Drug treatment options for the 2019new coronavirus (2019- nCoV). Biosci Trends 2020;P1-3.

45. Yao X, Ye F, Zhang $M$, et al. In Vitro Antiviral Activity and Projection of Optimized Dosing Design of Hydroxychloroquine for the Treatment of Severe Acute Respiratory Syndrome Main point: Hydroxychloroquine was found to be more potent than chloroquine at inhibiting SARSCoV-2 in vit. Clin Infect Dis 2020;2:1-25.

46. Picot S, Marty A, Bienvenu A-L, et al. Coalition: Advocacy for prospective clinical trials to test the post-exposure potential of hydroxychloroquine against COVID-19. One Heal [Internet] Elsevier B.V; 2020; Available from: https://doi.org/10.1016/j.onehlt.2020.100131

47. Gabriels J, Saleh M, Chang D, Epstein LM. Inpatient Use of Mobile Continuous Telemetry for COVID-19 Patients Treated with Hydroxychloroquine and Azithromycin. Hear Case Reports [Internet] Heart Rhythm Society; 2020; (PG-). Available from: http://www.sciencedirect.com/science/article/pii/S 2214027120300580 NS -

48. Gautret $\mathrm{P}$, Lagier J-C, Parola $\mathrm{P}$, et al. Hydroxychloroquine and azithromycin as a treatment of COVID-19: results of an open-label non-randomized clinical trial. Int J Antimicrob Agents [Internet] Elsevier B.V.; 2020;105949. Available from: https://doi.org/10.1016/j.ijantimicag.2020.105949

49. Wang $M$, Cao R, Zhang $L$, et al. Remdesivir and chloroquine effectively inhibit the recently emerged novel coronavirus (2019-nCoV) in vitro. Cell Res 2020;30(3):269-71.

50. Meynard JL, Moinot L, Landman R, et al. Week 96 efficacy of lopinavir/ritonavir monotherapy in virologically suppressed patients with HIV: A randomized non-inferiority trial (ANRS 140 DREAM). J Antimicrob Chemother $2018 ; 73(6): 1672-6$.

51. Chu CM, Cheng VCC, Hung IFN, et al. Role of lopinavir/ritonavir in the treatment of SARS: Initial virological and clinical findings. Thorax 2004;59(3):252-6.

52. Cai Q, Yang M, Liu D, et al. Experimental Treatment with Favipiravir for COVID-19: An Open-Label Control Study. Engineering [Internet] Chinese Academy of Engineering; 2020; (xxxx):4-
10. Available from:

https://doi.org/10.1016/j.eng.2020.03.007

53. Lythgoe MP, Middleton P. Ongoing Clinical

Trials for the Management of the COVID-19

Pandemic. Trends Pharmacol Sci [Internet]

Elsevier Ltd; 2020;xx(xx):1-20. Available from: https://doi.org/10.1016/j.tips.2020.03.006

54. Elfiky AA. Ribavirin, Remdesivir, Sofosbuvir, Galidesivir, and Tenofovir against SARS-CoV-2 RNA dependent RNA polymerase (RdRp): A molecular docking study. Life Sci [Internet] Elsevier Inc; 2020;117592. Available from: https://doi.org/10.1016/j.Ifs.2020.117592

55. Baron SA, Devaux C, Colson P, Raoult D, Rolain J-M. Teicoplanin: an alternative drug for the treatment of COVID-19? Int J Antimicrob Agents [Internet] Elsevier B.V.; 2020;2(xxxx):105944. Available from:

https://doi.org/10.1016/j.ijantimicag.2020.105944

56. Sallard E, Lescure FX, Yazdanpanah $Y$, Mentre F, Peiffer-Smadja N. Type 1 interferons as a potential treatment against COVID-19. Antiviral Res 2020;178.

57. Chan JFW, Yao Y, Yeung M-L, et al. Treatment with lopinavir/ritonavir or interferon$\beta 1 b$ improves outcome of MERS-CoV infection in a non-human primate model of common marmoset. J Infecteous Dis 2015;212(12):1904-13.

58. Brown BL, Mccullough J. Treatment for emerging viruses: Convalescent plasma and COVID-19. Transfus Apher Sci [Internet] Elsevier Ltd; 2020;102790. Available from: https://doi.org/ 10.1016/j.transci.2020.102790

59. Mohamed T, El-aziz A, Stockand JD. Recent progress and challenges in drug development against COVID-19 coronavirus ( SARS-CoV-2 ) - an update on the status. Infect Genet Evol [Internet] Elsevier; 2020;83:104327. Available from: https:// doi.org/10.1016/j.meegid.2020.104327

60. Tripathy S, Kar S, Chattopadhyay S, Das S. A novel chitosan based antimalarial drug delivery against Plasmodium berghei infection. Acta Trop [Internet] Elsevier B.V.; 2013;128(3):494-503. Available from: http://dx.doi.org/10.1016/j.actatropica.2013.07.0 11

61. Adewuyi S, Sanyaolu NO, Amolegbe SA, Sobola AO, Folarin OM. Poly[ $\beta-(1 \rightarrow 4)-2$-amino-2deoxy-D-ghicopyranose] based zero valent nickel nanocomposite for efficient reduction of nitrate in water. J Environ Sci (China) 2012;24(9):1702-8. 
62. Ahmed F, Soliman FM, Adly MA, Soliman HAM, El-Matbouli M, Saleh M. Recent progress in biomedical applications of chitosan and its nanocomposites in aquaculture: A review. Res Vet Sci [Internet] Elsevier; 2019;126:68-82. Available from: https://doi.org/10.1016/j.rvsc.2019.08.005

63. Chylińska M, Kaczmarek H, Burkowska-But A. Preparation and characteristics of antibacterial chitosan films modified with $\mathrm{N}$-halamine for biomedical application. Colloids Surfaces $B$ Biointerfaces 2019;176:379-86.

64. Ejeromedoghene, Onome., Alayande, J. Olalekan., Olatunji, D. Emmanuel ., Alli , A. Yakubu., and Adewuyi S. Synthesis of ChitosanZirconium(IV) Complexes as an Antifungal Spraying Agent Against Tomato Infected Aspergillus Niger. J Chem Soc Niger [Internet] 2019;44(1):125-9. Available from: http://journals.chemsociety.org.ng/index.php/jcsn /article/view/253

65. Wang $X$, Du Y, Fan L, Liu H, Hu Y. Chitosan- metal complexes as antimicrobial agent: Synthesis, characterization and Structure-activity study. Polym Bull 2005;113:105-13.

66. Huang J, Cheng Y, Wu Y, Shi X, Du Y, Deng $\mathrm{H}$. Chitosan/tannic acid bilayers layer-by-layer deposited cellulose nanofibrous mats for antibacterial application. Int J Biol Macromol [Internet] Elsevier B.V.; 2019;139:191-8. Available from:

https://doi.org/10.1016/j.ijbiomac.2019.07.185

67. Fotoran WL, Müntefering $\mathrm{T}$, Kleiber $\mathrm{N}$, et al. A multilamellar nanoliposome stabilized by interlayer

hydrogen bonds increases antimalarial drug efficacy. Nanomedicine Nanotechnology, Biol Med [Internet] Elsevier Inc. ; 2019;22:102099. Available from:

https://doi.org/10.1016/j.nano.2019.102099

68. Adewuyi S, Kareem KT, Atayese AO, Amolegbe SA, Akinremi CA. Chitosan-cobalt(II) and nickel(II) chelates as antibacterial agents. Int J Biol Macromol [Internet] Elsevier B.V.; 2011;48(2):301-3. Available from: http://dx.doi.org/10.1016/j.ijbiomac.2010.12.004

69. Loh XJ, Wu YL. Cationic star copolymers based on $\beta$-cyclodextrins for efficient gene delivery to mouse embryonic stem cell colonies. Chem Commun [Internet] Royal Society of Chemistry; 2015;51(54):10815-8. Available from: http://dx.doi.org/10.1039/C5CC03686K

70. Loh XJ, Ong SJ, Tung YT, Choo HT. Codelivery of drug and DNA from cationic dual- responsive micelles derived from poly(DMAEMA-coPPGMA). Mater Sci Eng C [Internet] Elsevier B.V.; 2013;33(8):4545-50. Available from:

http://dx.doi.org/10.1016/j.msec.2013.07.011

71. Xiang Y, Nwe N, Oo L, Lee JP, Li Z, Loh XJ. Recent development of synthetic nonviral systems for sustained gene delivery. Drug Discov Today [Internet] Elsevier Ltd; 2017;22(9):1318-35. Available from:

http://dx.doi.org/10.1016/j.drudis.2017.04.001

72. Ahsan SM, Thomas M, Reddy KK, Gopal S, Asthana A, Bhatnagar I. Chitosan as biomaterial in drug delivery and tissue engineering. Int $\mathrm{J} \mathrm{Biol}$ Macromol [Internet] Elsevier B.V.; 2018;110:97109. Available from:

http://dx.doi.org/10.1016/j.ijbiomac.2017.08.140

73. Mao S, Sun W, Kissel T. Chitosan-based formulations for delivery of DNA and siRNA. Adv Drug Deliv Rev [Internet] Elsevier B.V.; 2010;62(1):12-27. Available from: http://dx.doi.org/10.1016/j.addr.2009.08.004

74. Mansouri S, Lavigne $\mathrm{P}$, Corsi $\mathrm{K}$, Benderdour M, Beaumont E, Fernandes JC. Chitosan-DNA nanoparticles as non-viral vectors in gene therapy: strategies to improve transfection efficacy. Eur $\mathrm{J}$ Pharm Biopharm 2004;57:1-8.

75. Buschmann MD, Merzouki A, Lavertu M, Thibault M, Jean M, Darras V. Chitosans for delivery of nucleic acids. Adv Drug Deliv Rev [Internet] Elsevier B.V.; 2013;65(9):1234-70. Available from:

http://dx.doi.org/10.1016/j.addr.2013.07.005

76. Tripathy S, Das S, Prasad S, Kumar S, Pramanik P, Roy S. Synthesis, characterization of chitosan - tripolyphosphate conjugated chloroquine nanoparticle and its in vivo antimalarial efficacy against rodent parasite: A dose and duration dependent approach. Int J Pharm [Internet] Elsevier B.V.; 2012;434(1-2):292-305. Available from:

http://dx.doi.org/10.1016/j.ijpharm.2012.05.064

77. Magalhães GA, Moura E, Sombra VG, et al Chitosan / Sterculia striata polysaccharides nanocomplex as a potential chloroquine drug release device. Int $\mathrm{J}$ Biol Macromol [Internet] Elsevier B.V.; 2016;88:244-53. Available from: http://dx.doi.org/10.1016/j.ijbiomac.2016.03.070

78. Usman M, Akhyar Farrukh M. Formulation of polymeric iron nano-chloroquine phosphate antimalarial drug via polyol method. Mater Today Proc [Internet] Elsevier Ltd; 2018;5(7):15595-602. Available from:

https://doi.org/10.1016/j.matpr.2018.04.168 
79. Fantini J, Scala C Di, Chahinian H, Yahi N. Structural and molecular modeling studies reveal a new mechanism of action of chloroquine and hydroxychloroquine against SARS-CoV-2 infection. Int J Antimicrob Agents [Internet] Elsevier B.V.; 2020;105960. Available from:

http://www.ncbi.nlm.nih.gov/pubmed/32251731

80. Sahraei Z, Shabani M, Shokouhi S, Saffaei A. Aminoquinolines Against Coronavirus Disease 2019 (COVID-19): Chloroquine or Hydroxychloroquine. Int $J$ Antimicrob Agents [Internet] Elsevier B.V.; 2020;2019(xxxx):105945. Available from:

https://doi.org/10.1016/j.ijantimicag.2020.105945

81. Jorge AM, Melles RB, Zhang $Y$, et al. Hydroxychloroquine prescription trends and predictors for excess dosing per recent ophthalmology guidelines. Arthritis Res Ther 2018;20(1):4-11.

\section{Lim HS, Im JS, Cho JY, et al.}

Pharmacokinetics of hydroxychloroquine and its clinical implications in chemoprophylaxis against malaria caused by plasmodium vivax. Antimicrob Agents Chemother 2009;53(4):1468-75.

83. Ravi PR, Vats R, Balija J, Adapa SPN, Aditya N. Modified pullulan nanoparticles for oral delivery of lopinavir: Formulation and pharmacokinetic evaluation. Carbohydr Polym [Internet] Elsevier Ltd. ; 2014;110:320-8. Available from: http://dx.doi.org/10.1016/j.carbpol.2014.03.099

84. Kozhikhova K V., Ivantsova MN, Tokareva MI, et al. Preparation of chitosan-coated liposomes as a novel carrier system for the antiviral drug Triazavirin. Pharm Dev Technol [Internet] Taylor \& Francis; 2018;23(4):334-42. Available from: http://dx.doi.org/10.1080/10837450.2016.124262 4

85. Cánepa C, Imperiale JC, Berini CA, Lewicki M, Sosnik A, Biglione MM. Development of a Drug Delivery System Based on Chitosan Nanoparticles for Oral Administration of Interferon-a.

Biomacromolecules 2017;18(10):3302-9.

86. Donalisio M, Leone F, Civra A, et al. Acyclovir-loaded chitosan nanospheres from nanoemulsion templating for the topical treatment of herpesviruses infections. Pharmaceutics $2018 ; 10(2): 1-12$.

87. Ulla F, Javed F, Khan AN, et al. Synthesis and surface modification of chitosan built nanohydrogel with antiviral and antimicrobial agent for controlled drug delivery. Biointerface Res Appl
Chem [Internet] 2019;9(6):4439-45. Available from: https://doi.org/10.33263/BRIAC96.439445

88. Russo E, Gaglianone N, Baldassari S, et al. Preparation, characterization and in vitro antiviral activity evaluation of foscarnet-chitosan nanoparticles. Colloids Surfaces B Biointerfaces [Internet] Elsevier B.V.; 2014;118:117-25. Available from:

http://dx.doi.org/10.1016/j.colsurfb.2014.03.037

89. Yang L, Chen L, Zeng R, et al. Synthesis, nanosizing and in vitro drug release of a novel anti-HIV polymeric prodrug: Chitosan-O-isopropyl5'-O-d4T monophosphate conjugate. Bioorganic Med Chem [Internet] Elsevier Ltd; 2010;18(1):117-23. Available from: http://dx.doi.org/10.1016/j.bmc.2009.11.013

90. Yan JK, Wang YY, Qiu WY, Wu JY. Construction and characterization of nanosized curdlan sulfate/chitosan polyelectrolyte complex toward drug release of zidovudine. Carbohydr Polym [Internet] Elsevier Ltd.; 2017;174:209-16. Available from:

http://dx.doi.org/10.1016/j.carbpol.2017.06.082

91. Cazorla-Luna R, Notario-Pérez F, MartínIllana $A$, et al. Chitosan-based mucoadhesive vaginal tablets for controlled release of the antiHIV drug tenofovir. Pharmaceutics 2019;11(1).

92. Wu D, Ensinas A, Verrier B, et al. Zincstabilized chitosan-chondroitin sulfate nanocomplexes for HIV-1 infection inhibition application. Mol Pharm 2016;13(9):3279-91.

93. Graham BS. Advances in antiviral vaccine development. Immunol Rev 2013;255(1):230-42.

94. Ellebedy AH, Ahmed R. Antiviral Vaccines: Challenges and Advances. Vaccine $B$ Second Ed Second. Elsevier Inc.; 2016. p. 283-310.

95. Ellebedy $\mathrm{AH}$, Webby RJ. Influenza vaccines. Vaccine $2009 ; 27($ SUPPL. 4):65-8.

96. Muralidharan A, Russell MS, Larocque L, et al. Chitosan alters inactivated respiratory syncytial virus vaccine elicited immune responses without affecting lung histopathology in mice. Vaccine [Internet] Elsevier Ltd; 2019;37(30):4031-9. Available from:

https://doi.org/10.1016/j.vaccine.2019.06.003

97. Spinner JL, Oberoi HS, Yorgensen YM, et al. Methylglycol chitosan and a synthetic TLR4 agonist enhance immune responses to influenza vaccine administered sublingually. Vaccine [Internet] Elsevier Ltd; 2015;33(43):5845-53. Available from: 
http://dx.doi.org/10.1016/j.vaccine.2015.08.086

98. Renu S, Feliciano-Ruiz N, Ghimire S, et al. Poly(I:C) augments inactivated influenza viruschitosan nanovaccine induced cell mediated immune response in pigs vaccinated intranasally. Vet Microbiol [Internet] Elsevier;

2020;242(January):108611. Available from: https://doi.org/10.1016/j.vetmic.2020.108611
99. El-Sissi AF, Mohamed FH, Danial NM, Gaballah AQ, Ali KA. Chitosan and chitosan nanoparticles as adjuvant in local Rift Valley Fever inactivated vaccine. 3 Biotech [Internet] Springer International Publishing; 2020;10(3):1-11. Available from: https://doi.org/10.1007/s13205020-2076-y 